\title{
An Evaluation of Turkish Teacher Education System Compared to Other Models in Different Countries
}

\author{
Tayyip DUMAN', Savaş KARAGÖZ²
}

\section{ARTICLE INFO \\ Article History: \\ Received 02.09.2015 \\ Received in revised form \\ 10.10.2015 \\ Accepted 20.11.2015 \\ Available online 01.01.2016}

\begin{abstract}
Teachers and their education, as the most important elements in educational systems, have been one of the mostly debated issues in Turkish national education system. The success of an education system largely depends on the quality of the teachers who plan and practice teaching and learning process. Reviewing Turkish educational history with a well-established tradition of education reveals a rich experience in teacher training within this tradition. The main objective of this study is to examine teacher training policies and practices from 1848 to these days in Turkey, and to compare the Turkish teacher training system to the current teacher training models applied in different countries. This survey research has been conducted based on the literature review. Not yet completed, some of its recent results obtained are as follows: Teachers in Turkey were regarded as the main agent of educational innovation, and teacher education was discussed as an issue within educational reform. Turkey, to the present day from 1848, the date when first teacher training institution was founded in the country, during the Republican era in particular, had many teacher training institutions and practiced many different training models considering the socio-economic, cultural and political conditions. In spite of some similarities to other models in different countries, Turkish teacher training system shows originality and richness in terms of its features.

C 2016 IJERE. All rights reserved

Keywords:

Teacher, teacher education policy, teacher education system, teacher education model
\end{abstract}

\section{Introduction}

Teachers and their education, as the most important elements in educational systems, have been one of the mostly debated issues in Turkish National Education System. The success of an education system largely depends on the quality of the teachers who plan and practice teaching and learning process. On the other hand, teacher training is a versatile and complicated problem. In the process of establishing new teacher training systems or analyzing the current ones, the following questions should be answered: What kind of a teacher is needed? What is the current role and the desired role of a teacher in changing and developing societies? Which institutions should train teacher candidates? What is the intended structure, status, duration of education and curriculum of these institutions? What are the criterions in selecting new students to these institutions? Which procedures should be used in appointment and in-service training of teachers? What is the role and the status of a teacher in society? Reviewing Turkish educational history with a wellestablished tradition of education reveals a rich experience in teacher training within this tradition. Analyzing Turkish teacher training system within these questions uncovers various significant implications. In this study, teacher training policies and practices from 1848 to these days in Turkey are examined and Turkish teacher training system is investigated in comparison with current teacher training models applied in different countries. This survey research has been conducted based on the literature review.

\section{Education and Teacher Training in Pre-Republican Period}

In Turkey, the problem of teacher training was evaluated within the reform movement in education before the establishment of Republic in Tanzimat Reform Era. As it is known, Ottoman Empire inherited its education system based on the Madrasah system from Seljuks. The Ottoman Empire improved and 
enhanced this system in foundation and rise periods. These institutions had served for Ottoman society for a long time. However; new institutions were needed as they didn't adapt themselves to the current conditions. Therefore; new institutions were established primarily in military field than in civilian field within the westernization and modernization movements started after the first quarter of 18th century.( Koçer, 1987,s1) These institutions were different from traditional Ottoman institutions and they were established by imitating the western ones. The aim of military institutions was to train soldiers for the Ottoman Empire Army in order to prevent the army from regression. On the other hand; civilian institutions aimed at training officials for the reorganized state organization and supplying students for military academy. These new institutions that were different from Traditional Ottoman Education Institutions were in need of new teachers. It was impossible for this reform movement to be successful with Madrasah graduate teachers( muallim) and professors (müderris). Therefore; in modern sense, the first Teacher Training Institution, Darülmuallimin, was established thanks to statesmen and educators in order to train teachers for junior high schools (Rüştiyeler) in Istanbul on the 16h of March ,1948. ( Unat, 1964, s.30). This institution followed in 1868 by Darülmuallimin-i Sibyan( Normal Schools for Primary School Teachers) that was established in Istanbul in order to train teachers for primary schools (Sibyan Mektepleri). After this development, Darülmuallimin ( Teacher Training School for Boys) was called Darülmuallimin-i Rüşdi. Although Tanzimat era Ottoman intellectuals started to establish modern institutions apart from the Madrasah system, most of them could be established thanks to the special effort of some statesmen. As these reform movements were sticked to a plan, they couldn't be a government policy. Aiming to fill this gap, Maarif-i Umumiye Nizamnamesi (General Regulations for National Education) was published in 1869. This regulation regarded education as state's responsibility and aimed at establishing a new education system from primary school to university. In addition, taking the teacher demand in consideration, it followed an appropriate path in training new teachers for the future education system. As it is mentioned above, two Teacher Training Institutions called Darülmuallimin-i Rüşdi(Secondary School Teacher Training Institution) and Darülmuallin-i Sıbyan ( Primary School Teacher Training Institution) were established in 1869 before the publication of Regulations. On the other hand, two more Teacher Training Institutions, Büyük Darülmuallimin(Teacher Training School for Boys) and Darülmuallimat ( Teacher Training School for Girls), were established with the publication of Regulations.( Koçer, 1975, s.7). The aim of Büyük Darülmuallimin was to train teachers for its branches respectively rüşdiye, idadiye and sultaniye. On the other hand; the aim of Darulmuallimat and Kız Rüştiyeleri( Secondary Schools for Girls) was to train female teachers for Sıbyan Schools. In spite of all of these reformative attempts of regulations aforementioned decisions on training teachers couldn't be implemented completely and timely like some others. Darülmuallimat,Teacher Training School for Girls, was the first teacher training institution established after the publication of Regulations. This institution was established in Istanbul in 1870 with the aim of supplying female teachers for Kız Rüştiyeleri and Sıbyan Schools that were started to be established from 1859 and had been increasing in number day by day. Foundation of Büyük Darülmuallimin that was planned in Regulations could be achieved after 8 years in 1877. However; only one of its branches, idadiye, was established and it was taken under the control of the same supervisor with Darülmuallimin-i Rüşdi. It couldn't survive so long and closed in 1880. However; the most efficient and constant attempt on this institution was made at the beginning of 1890 . As a result, it was re-opened as Darülmuallimin-i Aliye in 1891. Therefore; as it was planned in Regulations in 1869, foundation of teacher training institutions was completed and various teacher training institutions were founded for every educational stages. ( Duman,1999,ss.306-315). However, unfortunately these institutions were started to be established outside Istanbul and they couldn't be aware of the madrasah effect. As a result of closing or frequent changes in curriculum, they couldn't function systematically and consistently. In spite of these disappointments, in the second half of 19th century, critical attempts were made in teacher training within the reform movement in education and curriculum of teacher training institutions was enriched with some courses such as teaching methods and professional teaching 
knowledge. ( Duman ve Dilaver, 1996, ss. 651-662) In Pre-Republican period, new ideas on education and teacher training were made, discussed and even some of them were implemented in Second Constitutional Period.In this period continued 10 years from 1908, critical attempts were made in every stage and field of education from pre-school to university including teacher training. Significant progresses were made in quantity and at a lesser extent in quality. Implications and suggested ideas on teacher training of this period can be summarized as follows: critical attempts were made in order to protect teacher training institutions from the madrasah effect and raise the quality of education. Duration of teacher training institutions was extended to three years from two years. On the other hand; courses such as painting and handicraft were added to the curriculum of these institutions and it was re-arranged by this way. Aiming to give teacher candidates the opportunity to practice, a practice school was founded within the teacher training institution. In order to handle with the quantity problem of primary school teachers, a new requirement called Certificate of Teaching ( Ehliyetnameli Öğretmenlik) was introduced. With the foundation of Darülmuallimin (1913) and Darülmuallimat (1915), the structure of teacher training institutions was reorganized and new branches were established. During this process, some of the preplanned branches were founded in order to train primary school inspectors and teachers for preschool, physical education, vocational education, teacher training schools for girls's and boys' founded in centers (vilayet and sancak) but eventually none of them could survive. ( Duman, 1991, s.17) Master Teacher School, one of the aforementioned departments, was established within Teacher Training School for Girls as it was proposed in Regulations. However; It closed after four years of functioning. In order to train teachers and primary school inspectors for the teacher training institutions outside Istanbul, 2 year Kısmi İhzari branches were established within Darülmuallimin-i Aliye and Darülmuallimat-1 Aliye. However; they closed as a result of war soon after. Establishment of training departments for physical education teachers and vocational teachers was proposed in Regulations. However; the plan couldn't be implemented. In the Constitituonal Period, various Teacher Training Institutions for Girls were established other than Rüştiye and these institutions increased the demand of female teachers. In order to train the needed teachers, (İnas Darülfünunu) Women's University was established within Teacher Training Schools for Girls Although some of these implications couldn't be achieved, on the subjects of education, teaching profession and training teachers, critical ideas that would pave the way for the works of Republican period were made in this period. Some of them are as follows: Education plays an important role for the future of Turkey and Teachers are pioneers of education. Teaching profession means primarily being an educator. Being an educator is a skill and an art. This art needs specific methods and rules. Teachers are need to be aware of them. In order to achieve this goal, curriculum of teacher training institutions should include these methods and rules. Sole purpose of teacher training institutions should be training teachers and they should serve for this purpose. Separate teacher training system should be implemented for villages. The dignity of teaching profession should be raised in order to supply high quality teachers. ( Akyüz, 2012, s. 394)

\section{Education and Teacher Training in Republican Period}

The pioneers who established Turkish Republic and reorganized social, cultural, political and economic structures of Turkish society established a national, contemporary, secular and democratic education system. Besides; they didn't neglect training teachers who would raise next generations that would raise and glorify the nation. Training teachers took an importance place within the reform movements in education. On this subject, the attempts were made in line with national education policy and country conditions. In the first years of Republic, especially in the Atatürk period, legal foundations of Turkish National Education System and teaching profession were laid. On the other hand, existing teacher training instutitions were reformed and new ones were established in line with the demand. The implications and developments in teacher 
training of Republican Period can be divided according to educational stages into two parts as pre-1982 post-1982. This can be summarized as follows:

\section{Primary School Teacher Training (1923-1982)}

As it is known, $80 \%$ of Turkish society who was tired and sick of wars but thanks to their determination and belief still gained victory under the leadership of Atatürk had been living in villages. There weren't any schools and teachers in almost all of the villages. This situation led Republican governments to give priority to primary education and to regard primary education as a problem of village education. Furthermore, in order to reorganize the structure of Republican period education system, Law No.789, Maarif Teşkilatı Kanunu [Law on the Education System] was enacted in 1926. This legislation divided primary education into two parts as city and village institutions and teacher training institutions as First Teacher Training Institutions and Village Teacher Training Institutions. Making primary education widespread and developing villages were the primary goals of education. Therefore; training primary school teachers was the focus of teacher training. With this aim; several attempts were made in order to reform and develop the first teacher training institutions. In addition; separate teacher training models were tried to be developed for the villages that were totally different from cities in terms of life conditions. At the beginning of 19231924 academic year, there were twenty Teacher Training Institutions for Girls and Boys. Most of these institutions were in need of teaching staff, student and building. Because of country conditions, teacher training institutions couldn't develop under the control of provincial private institutions. Therefore; they were taken under the control of board education and government budget as well. However; these precautions were not enough for developing teacher training institutions. The way of increasing quality of these institutions is to decrease them in number and bring them together in certain places. The plan was to establish Darülmuallimin Mıntıkaları( Districts of Teacher Training Institutions). In order to achieve these goals, Anatolia was divided into fifteen centers of teacher training institutions and the plan was put into practice as soon as possible. According to the decisions of Heyeti İlmiye ( The Council of Science and Education) conducted in the first years of Republic, duration of teacher training institutions was extended to five years from four years. Critical changes were made in curriculum in order to improve professional teaching knowledge ( Öztürk,1996,s.26) At the beginning of 1932-1933 academic year, duration of first teacher training institutions was extended to six years and they were divided into two stages as $3+3$. The first stage of these institutions(equivalent to secondary school) were not open to enrollment for a time and they turned into vocational high schools. However; in the following years, these institutions were opened to enrollment for primary school graduates. In 1970-1971 academic year, duration of teacher training institutions was extended to four years. In addition, they increased in number and finally they reached 89 . ( Duman, 2012, s. 368) In the first years of Republic, reformative movements were made for the existing teacher training institutions. Moreover, separate teacher training system , dated back to the Constitutional Period, became on the agenda for village that was totally different from city in terms of life conditions. At the time of Mustafa Necati, Minister of Education( Maarif Vekili), who focused on village education, two 3year Village Teacher Institutions ( Köy Muallim Mektebi) were established in Kayseri Zincidere and Denizli in 1926-1927 academic year. However; these institutions couldn't survive for a long time. They closed respectively in 1932 and in 1933. ( Karagöz,2005,s.10) Although these implications didn't cover the expectations, the plan of establishing a separate teacher training system for villages wasn't cancelled. This plan became on the agenda a few years later. In order to achieve this goal, Educator Courses were established for training teachers who were acquainted with village, villages and their needs. These 6-8 month courses including culture and agriculture lessons were arranged by Board of Education (Maarif Vekaleti ) and Ziraat Vekaleti( Board of Agriculture). Students were selected to these courses among village's young people who were literate, had maths knowledge and had served as a soldier. At the beginning, these 
courses had been established for trial purposes. However; after they resulted in success, Village Educator's Law ( Köy Eğitmenleri Kanunu) was enacted in 1937 in order to reorganize the courses and put them a legal basis. In 1937-1938 academic year. two Village Teacher Institutions were established respectively in Izmir, Kizılçullu and Mahmudiye, Çifteler. After the legislation of Village Institute Law in 1940, the problem of teacher training for villages came to an end with a substantial solution. In these leading Institutions of Turkish Education System, primary school graduate children of villagers were selected by examination and selected students attended to hands on training in these institutions. Furthermore, these institutions train teachers who would be a guide to villagers on agricultural, technical and health issues. Number of these institutions reached 21 in the course of time. On account of the fact that village and city difference was over, these institutions were assembled with Traditional First Teacher Training Institutions with the Law no 6234 in 1954.( Koçer, 1967,s.7) .The year of 1973 had critical importance both for Turkish National Education System and for Teacher training. Turkish National Education System was reorganized as a whole in terms of its purposes, principles, structure, foundation and functions with the National Education Basic Law ( Milli Eğitim Temel Kanunu) no 1739. On the other hand, duration of compulsory education, called "basic education", was extended to 8 years by dividing into two stages as $5+3$. With the "National Education Basic Law" (article 1739), it was determined that all teachers must earn higher education degrees. As a result, duration of pre-service teaching for preschool teachers and primary school teachers was extended to high school level from secondary school level. In 1974-1975 academic year, First Teacher Training Institutions were renamed as "Teacher High School" and some of the First Teacher Training Institutions were turned into two year Education Institutes in order to train teachers for the first stage of basic education. These institutions were devolved on universities after they re-named as" Education Higher School" with the delegated legislation no 41 in 1982( Duman,1998,ss.36-43)

\section{Secondary School Teacher Training ( 1923-1982)}

Turnining back to the beginning of Republican Period, the attempts and the progresses on secondary school teacher training within the reform movements in education can be summarized as follows: Republican governments gave due importance to secondary education but not as much as primary education. In this period, they reformed secondary schools, high schools and vocational technical school that were barely 158 in total. In addition they made various attempts to construct and generalize these institutions. Like primary education institutions, secondary education institutions were in need of building, equipment and money, too but the most important problem was demand for teachers. In the first stage continued from the establishment of Republic to Atatürk's death, various teacher training institutions that have had an important role in teacher training were established.. Although some of them closed, many of them have been surviving until today. Attempts on general and vocational secondary schools of this period can be summarized as follows:

\section{General Secondary School Teacher Training}

In this period, there were two significant institutions training high school and secondary school teachers. One of them was "Higher Teacher Schools" ( Yüksek Öğretmen Okulları) and the other one was "Education Institutes". Like "Village Institutes", these institutions also played an important role in the Turkish history of teacher training. Nowadays, these two institutions are mentioned in every meeting arranged for developing today's teacher training system. Especially "Higher Teacher Schools" are evaluated elaborately. These institutions that had served until mid-1970 and supplied eminent teachers for Turkish National Education System will be analyzed in detail as follows. As it can be remembered, "Higher Teacher School", Darülmuallimin-i Aliyye, was established as a 2 year institution in 1891 in order to train teachers for high schools (idadi) and higher institutions. In the following years, duration of this institution was extended to 
three years and they maintained their teaching activities alone or with Darülfunun (University) until the first years of Republic. When the Republican regime took over Darülmuallin-i Aliye, the students were studying in Darülfünun and they weren't taking pedagogical formation courses. The institution was torn betweeen Board of Education and Darülfunun. It was undistinguished from a hostel. Therefore; a critical decision was made in the first and second Committee of Science Meetings( Heyeti İlmiye Toplantıları) in order to reform these institutions. With the regulations of 1924, Board of Education reorganized the institution and renamed it as "Higher Teacher School" . Education period of which became four years. In addition, it provided free boarding education. The senior class stood for practice and traineeship. The students took major area courses from the related faculties. On the other hand, they took vocational lessons at "Higher Teacher School". In order to get a diploma from Higher Teacher School, students had to pass written and oral exams of vocational lessons apart from completing Darülfunun and they also had to completed traineeship successfully. During those dates, a high school diploma was enough for entering Darülfunun (university). However; students were selected for "Higher Teacher School" after they were subjected to a written and an oral examination by a committee including instructors of Faculty of Science and Literature under the chairmanship of director of the graduate school. The institution that was reorganized as Yüksek Ögrretmen Okulu right after the first National Education Council maintained teaching activities single-handedly until 1959.( Duman, 1991,s.160). As "Istanbul Higher Teacher School" couldn't supply the teacher demand of high schools and their equivalents, the authorities began searching for new sources. Students of this institution got their undergraduate degree from universities. As this implication turned out well, two more Higher Teacher Schools were established respectively in Ankara (1959) and in Izmir( 1964) However; these new institutions were a bit different from Istanbul Higher Teacher School. Students of these institutions were successful final year students of the first teacher training institutions who were selected by teacher committee of the related school. Selected students were subjected to a State's high school exit exam after they studied in prep class. The ones passed both this exam and university entrance exam became students of Higher Teacher School. After students were enrolled to the related departments in accordance with the high school teacher demand of the Ministry, they studied major area courses in the related faculties and pedagogical formation courses at Higher Teacher School. The school provided free boarding education.( Gelişli, 2006,s.45). As it became a successful model in which students got their undergraduate degree from the faculties of science and literature and selected among the eminent students of the first teacher training institutions, Istanbul Higher Teacher School began applying the same procedures. However; after the first teacher training institutions were transformed into Teacher High School, in other words, after they lost their students, Higher Teacher Schools were closed down in 1978. Attempts on secondary education and teacher training for these institutions in the first years of Republic can be summarized as follows: apart from reform movements on Higher Teacher Schools, At the beginning of 1923-1924 academic year, Secondary Teacher Training School for Girls' and Secondary Teacher Training School for Boys' within Istanbul Teacher Training School of Boys and Girls were established. However; they were closed down one year later and students were transferred to "Higher Teacher Schools." In 1924-1925 academic year, Ankara Music Teacher Training School (Ankara Musiki Muallim Mektebi) was established in order to train music teachers. Again during this period, a "Physical Education Teacher Training School "was decided to be established in order to train physical education teachers. However; this school got started its' training activities as a course in 1926. Apart from the attempts made during the first period of the Republic, the most persistent and rooted attempt on secondary teacher training was made at the beginning of 1926-1927 academic year. A two year college named as" Orta Muallim Mektebi"( Secondary Teacher Training School) was established just with its literature branch in Konya. The college was transferred to Ankara one year later and new branches were added.In addition, the duration of education was extended. Furthermore, the Institution took the name of Gazi Muallim Mektebi ve Terbiye Enstitüsü ( Gazi Secondary Teacher Training School and Civility Institute) In this institute, the duration of education differed depending on the departments. In 1940's new Education 
Institutes were added with the establishment of new institutions in Balıkesir, İstanbul, Bursa and Izmir.( Duman,2002,ss.127-132). With the generalization of secondary schools across the country, Education Institutes increased in number. Their numbers reached 10-18 respectively in 1960's-1970's. The duration of education had been three years for all departments of Education Institutes. However; in 1978-1979 academic year, they were renamed as "Higher Teacher School" and their duration was extended to 4 years. These Schools were renamed as "Faculty of Education" and transferred to universities in 1982. Education Institutes, graduates of which worked as a high school teacher but actually trained secondary school teachers were one of the significant institutions of Turkish Teacher Training History. The structure of these institutions and the conditions led them to be eminent will be analyzed in the following lines. All of these institutions provided boarding education in their first years. Students who were distinguished graduates of "First Teacher Training Institute", high school graduates or worked as a primary school teacher for a length of time were selected with an examination. Students were subjected to two separate exams as selection examination and entrance examination. Selection exams were written exams held in centers. On the other hand; Entrance exams were held in institutes and they varied as written, oral or practical tests depending on the departments. These exams tested not only knowledge and skills but also personality traits of a teacher. Furthermore, in order to take these exams, students must be presented as candidates by teacher committees and teachers must be presented as candidates by Directorates of National Education. The article 9 of Education Institute Regulations of 1995 puts this matter as follows: "During the selection process of candidates for high schools or teacher training institutes by teacher committees or Directorates of National Education, following items should be evaluated: the success of candidates during their secondary, high school or vocational high school education, their temperance, patience, compassion for children, interest levels of teaching and to others, talent of speaking, moral knowledge, national feelings, physical and emotional health, in the event of suspending his/her education, the occupation that he/she was engaged in.( Duman,1991,ss.163-167). In the following years, these institutions began accepting day students and even various day schools were established. In this institutions where teaching staff were selected meticulously, professional ideals and virtue of being a teacher were engrained in the heart of each teacher candidate.They gave the utmost importance to Professional teaching knowledge lessons and teaching practice. Actually most of these institutions had a "Practice School". Especially in the years when there were limited numbers of Institutes, they had distinguished teaching staff. In addition to lessons, social activities also took place in the curriculum. Moreover; one of the institutions aim was to instill patriotism, nationalism and the love of being a teacher. In this respect, following statements of Board of Education and Discipline dated 10.26.1957 numbered 236 have importance. "Teacher is the most important personnel of Education Institutes. He/She prepares students for the world of work by considering their future career during the lesson, practices and other educational activities. Teacher candidates have had love and excitement of being a teacher since their first year. This love and excitement can be gained through conferences, discussions, tours and interactions with the other institutes and secondary schools" In 1970's, while the education institutes were increasing in number, the quality of teachers and students couldn't be maintained. Each government accepted students and teaching staff in accordance with its political view. Anarchist movements of the time affected these institutions. Duration of these institutions was extended to 4 years in 1978 and they were restructured as " Higher Teacher School" . In order to enroll these institutions, students were subjected to a standardized test by OSYM ( Student Selection and Examination Center). However; the problems couldn't be resolved. As it is mentioned above, these institutions were devolved on universities in order to have more autonomous and academic structure. 


\section{Secondary Vocational and Technical School Teacher Training}

Vocational and Technical Education that hadn't been included in the education system and education policy of Pre-Republican Period became an important issue for Republican governments. They were primarily included into the system in order to be re-established and developed. With this aim, International experts were invited to Turkey. By benefiting from their knowledge, a National Vocational and Technical Education System was tried to be established and generalized. Teacher shortage was one of the problems of these institutions. In order to train teachers for these institutions, Students were sent to Europe and Teachers were brought from abroad. However; they were temporary precautions. Finally, in order to train vocational teachers for "Girls' Institutes( Kız Enstitüleri) and Evening Girls' Art School (Akşam Kız Sanat Okulu), " Vocational Teacher School for Girls" (Kı Meslek Öğretmen Okulu) was established in Ankara in 1934-1935 academic year. On the other hand, in 1937-1938 academic year, , "Vocational Teacher School for Boys" (Erkek Meslek Öğretmen Okulu) was established in Ankara in order to train vocational teachers for "Boys' Art School" (Erkek Sanat Okulları). In 1946, in accordance with the Third National Education Council (Üçüncü Milli Eğitim Şurası), duration of these schools were extended to four years from three years and they were renamed as "Technical Teacher School for Girls"(Kız Teknik Öğretmen Okulu) and “Technical Teacher School for Boys"(Erkek Teknik Öğretmen Okulu). In accordance with the Seventh National Education Council (7.Milli Eğitim Şurası), these institutions were renamed as "Technical Higher Teacher School for Girls" (Kız Teknik Yüksek Öğretmen Okulu) and "Technical Higher Teacher School for Boys" (Erkek Teknik Yüksek Öğretmen Okulu) in 1962. A new institution was established in mid-1950. In 19551956 academic year, 3 year " Commerce Teacher School (Ticaret Öğretmen Okulu) was established in order to train vocational teachers for "Commerce High Schools". In 1962, duration of this school was extended to four years and it was renamed as" Commerce and Tourism Higher Teacher School"( Ticaret ve Turizm Yüksek Öğretmen Okulu).( Duman, 1991,s.75) These teacher training schools were subjected to Ministry of National Education and they were all boarding schools. Students' of these institutions were selected with an examination. Graduates of Girls' Institutes( Girls' Vocational School) were selected for " Technical Higher Teacher School for Girls”(Kı Teknik Yüksek Öğretmen Okulu). Graduates of Art Institute(Industrial Vocational High School) were selected for " Technical Higher Teacher School for Boys" (Erkek Teknik Yüksek Öğretmen Okulu). Graduates of Commerce High School were selected for "Commerce and Tourism Higher Teacher School". Students must be presented as candidates in order to take the selection exam. The procedures were the same with the Education Institutes. As these institutions were separate, they didn't end up like "Education Institutes". They maintained their educational activities successfully by teaching field and vocational knowledge, instilling love of being a teacher with its' distinguished teaching staff and distinguished students until they were subjected to universities. In 1982, "Technical Higher Teacher School for Girls" was restructured as "Faculty of Vocational Education"(Mesleki Eğitim Fakültesi )and subjected to Gazi University. On the other hand, "Commerce and Tourism Higher Teacher School" was included in the same faculty with the name of "Department of Commerce and Tourism Education" (Ticaret ve Turizm Eğitimi Bölümü). At the same date, " Higher Teacher Schools for Boys" were renamed as "Technical Higher Teacher School" and reached two after one more was established in Istanbul. Then, they were restructured with the name of "Faculty of Technical Education"( Teknik Eğitim Fakültesi )and subjected to the related faculties. 


\section{Developments and Problems occurred After Teacher Training Instutitions were devolved on Universities.(1982-2015)}

At the beginning of 1980's some significant decisions were made and performed in Turkish higher education system and teacher education. In 1981, In accordance with the new Higher Education Law( No. 2547) principles related to the organization, functioning, duties, authority, and responsibilities of all higher education institutions and their governing bodies except institutions of higher education of the Turkish Armed Forces and Security Organization that differed in establishment, structure and functioning were established in connection with education, research, publication, teaching staff, students and other personnel of institutions of higher education. In 1982, with the acceptance of the law no 41 Decree Law, all higher education institutions of Ministry of National Education conducting teacher education was left to the universities. In this way the matter of teacher training has been retrieved a new constitution, status and functioning. With this new system, Education Institutes, which had trained teachers for primary schools, were renamed Education Higher Schools, Higher Teacher Training Schools, which had trained teachers for general and vocational secondary schools, were renamed Faculty of Education, Girls' Technical Higher Teacher Training Schools, Commerce-Tourism Higher Teacher Training Schools and Industrial Arts Higher Teacher Training Schools were renamed Faculty of Vocational Education, Technical Higher Teacher Training Schools were renamed Faculty of Technical Education, by these new names they restructured. After teacher education was totally left to universities, there has been various noticeable developments on this topic. Education duration of two-year period of Education Higher Schools were extended to four year period since 1989-90 academic year. With the law no 3837 that was enacted on July the 3rd, 1992, the Education Higher Schools were renamed Faculty of Education and duration of all teachers' pre-service education was extended to undergraduate level. In accordance with the above said law, Commerce-Tourism Education department existing within the Faculty of Vocational Education was transformed to Faculty of Commerce-Tourism Education, Technology education was transformed to Faculty of Industrial Arts Education, Girls' Arts Education Higher School as a department of Faculty of Vocational Education was transformed to Faculty of General Vocational Education and lastly Konya Selcuk University Girls' Arts Education Higher School was transformed to Faculty of Vocational Education. In the new teacher education system, another structural change was occurred in accordance with Higher Education Executive Board's decision dated 11/4/1997 and numbered 97.99.2761, which was made for performing from 1998-1999 academic year. With this decision, faculty of education was restructured. While all teacher education departments( pre-school, primary and secondary school teacher education) except vocational-technical education were brought together under restructured departments at Faculty of Education, duration of secondary school teacher education for the fields of science, math and social sciences was extended to graduate level by adding 1.5 years to 3.5. The duration of pedagogical formation education for graduates of faculty of science and literature was determined as 1.5 years.

\section{Teacher Education Models and Practices in Different Countries}

Present teacher education in Turkey as a selective and meticulous country in choosing students and instructors for teacher training institutes and in training and appointing teacher candidates in the past and as a country that has a rooted and substantial experience in teacher training is as mentioned above. So what about the other countries? Which models are applied for teacher education in America and EU member states? In order to evaluate teacher education in Turkey, teacher education models of these countries will be briefly analyzed. Teacher education in these countries can be summarized as four different models. 


\section{MODEL 1}

Educational Field+ Professional Teaching Knowledge Lessons+ Teaching Practices (including general and compulsory lessons)

In this model, teacher candidates take all lessons from the same institution. While for the first two years lessons relating to educational field are mainly given, for the last years lessons are turned into professional disciplines. Professional teaching knowledge lessons and practices are mainly given in third and fourth years.

\section{MODEL 2}

Undergraduate education+ teaching knowledge+ Teaching Practices (including general and compulsory lessons)

In this model, teacher candidates enroll in faculty of science and literature. They take lessons relating to their educational field from their faculties. However, lessons relating to teaching knowledge and practices are given in related faculties and departments in parallel with their undergraduate education.

\section{MODEL 3}

Undergraduate Education+ Teaching Knowledge and Practice

In this model, Graduates who have completed their undergraduate education in an educational field are given teaching certificate in two or four academic terms.

\section{MODEL 4}

In this model, students enroll in Faculty of Education. In their freshman year, general compulsory lessons are given to the students and they are also responsible for classroom observation that have certain credits and is practiced in diverse school settings. At the beginning of the second year, Teacher candidates make their decisions about school levels at which they aim to teach. Second term of the third year is dedicated to teaching practices. While students take their credit courses relating to their educational fields from Faculty of Science and Literature or other related faculties, they take teaching knowledge courses from Faculty of Education. In the fourth year, students are given additional courses relating to their educational fields and problems occurring in practices are discussed. Moreover, every student is assigned to deliver a written analysis in teaching-learning field.( Duman,1995,ss.40-48). When aforesaid teacher education models of different countries are examined in terms of key elements and key processes, it is clearly seen that these countries are still so selective and meticulous in selecting, training, assessing students and in appointing graduates as it was meticulously performed in Turkey before 1982.

\section{Selecting Students}

Teacher training programs are organized as teacher education programs or teacher education courses. These programs are applied in institutions such as faculty of education, teachers college, institute of education and higher teacher education school. These programs include major area courses, pedagogical formation lessons, general culture lessons and teaching practices. Essential elements of these programs are course subjects, homeworks, seminars and theses related to subjects.

Assessing Students 
Assessment begins with selecting process and it continues in training and appointing processes. In general assessment of teacher candidates, some measures are used like graduation thesis, student counselors' and supervisors' reports, self-assessment of teacher candidates, their performances of joining discussions, observance of professional principles and norms as well as students' success.

\section{Appointing Graduates}

Having a graduate diploma of teaching or a certificate of teaching don't ensure appointing as a teacher throughout the world. The appointing process starts with an announcement of vacancy .Then it continues with the announcement of application requirements and required qualifications. Application documents are assessed and in case of need, candidates are subjected to an interview or an exam. Moreover, candidates are asked for additional information or documents and they are evaluated in terms of experience and reference when required. Candidates are appointed for a period of one or two years in most of the EU member states. Teacher candidates are evaluated in terms of their teaching performance and efforts they make to improve themselves. Therefore; some activities have vital importance during the process like following professional publications and events relating to field at university, assisting to and cooperating with school management, preparing reports or giving seminars.

\section{Evaluation of Turkish Teacher Education System Compared to Other Models in Different Countries}

When Turkey's teacher education system is subjected to a general evaluation from the establishment of the first teacher training institute to date, it is clearly seen that teachers have been regarded as keys to reaching the goals of educational reforms and the institutes have aimed to nurture well-educated teachers who have the required qualifications of the new education system by taking the country's needs into consideration. Especially in the Republican Period, teachers were attributed the responsibility of raising the next generations who would glorify and keep Turkish Republic alive. In addition, with the establishment of Village Teacher Institutions and Village Institutes, the aim was to nurture teachers who had the required qualifications to educate village where the most of the population lived, villagers and their children in every respect and to play a role in society's enlightenment and development. In the following years, various important changes were brought in requirements to be a teacher and structure, status and curriculum of teacher training institutes by considering changing and developing socioeconomic circumstances of the country and contemporary pedagogy approaches. These changes had positive effects in general. Since 1982, in Turkey, teachers have been training in 4-year faculty programmes and in master's degree level at university, like in America and EU member states. Before 1982, Turkey applied similar standards and principles that are used in selecting, training, assessing and appointing students in other countries at the present time. In Turkey, Teacher Candidates were trained in Initial Teacher Training Institutions, Village institutes, Institutes of Education and Higher Teacher Education Institutions where students and teachers were selected meticulously and teachers were trained and appointed by providing professional ideals and virtue. In parallel with the developments in the World, teacher training institutions were devolved on universities. In addition, duration of all teachers' pre-service education was extended to undergraduate level and duration of some secondary education teacher training programs was extended to graduate level. Although teacher training got an academic structure and status thanks to the devolvement to universities, Contrary to expectations and things to do, Turkish teacher education system started to concentrate largely on number of the teachers, Instead of concentrating on qualification and professional practice of selected instructors and students, which was performed meticulously in the previous years when turkey was in need of more teachers. In the new system, a large number of Faculties of Education was established without considering the teacher need of the Ministry of Education, the number and qualification of instructors and equipment. Faculty of Vocational and Technical Education that trained teachers for secondary vocational 
and technical education institutions was closed. On the other hand, duration of pedagogical formation education was reduced gradually to one year and to 3.5 month and generalized. As a result, teaching has become a certificated profession that everyone who has a bachelor's degree can do.

\section{Conclusion and Recommendations}

Recently, Turkey with a well-established tradition of education and rich experiences in teacher training within this tradition have been pursuing teacher training policies that depend largely on quantity instead of quality. While this approach affects the quality of teachers in a negative way, it also decreases the prestige of the job as a result of growing numbers of teachers waiting for appointment and a common idea of being a teacher with a three month course. As the education system is one of the most critical factors for the development of a country and teachers are the most critical parts of this system, Turkey needs to review its teacher training policies by taking lessons from past experiences. In these new teacher training policies, Turkey is supposed to train highly qualified teachers by managing supply and demand. In addition, implications reducing the quality need to be removed from the training process. To conclude, in selecting new students, future demand for teachers and employment planning should be taken into consideration. In addition, after accrediting existing Education Faculties, students' admission should be terminated for under qualified faculties.

\section{References}

Akyüz, Y. (1990). Darülmuallimin'in ilk nizamnamesi (1851), önemi ve Ahmet Cevdet Paşa. Milli Ĕğitim, Say1: 95, Mart 1990, ss.3-20.

Akyüz, Y. (2012). Türk eğitim tarihi M.Ö. 1000 - M.S. 2012. (23. Bask1).Ankara: Pegem Akademi.

Duman, T. (1991). Türkiye'de ortaöğretime öğretmen yetiştirme (Tarihi Gelişimi), İstanbul: Milli Eğitim Basımevi.

Duman, T. (1995). Öğretmen yetiştirmede modeler. Milli eğitimin temel esasları ve hedefleri açısından öğretmenlik mesleği (Tebliğler). Ankara: Türk Yurdu. Türk Yurdu Yayınları No 20. ss.40-48.

Duman, T. (1998). Cumhuriyetimizin 75. yılında öğretmen yetiştirme sistemimiz ve sorunları. Milli Eğitim. Sayı 139, ss.36-43.

Duman, T. (1999). Osmanlıda öğretmen yetiştirme sistemi. Osmanlı Dergisi, Cilt 5, (S. 14), ss.306-315.

Duman, T. (1999). Türkiye'de eğitim reformlari açısından öğretmen yetiştirme sorunu. Erdem. Cilt 12, (S.34), ss. 91-107.

Duman, T. (2002). Gazi muallim mektebi ve terbiye enstitüsü.Türk Yurdu. Cilt 22, (S. 176), ss.127-132.

Duman, T. (2012). Öğretmen yetiştirme alanındaki uygulamalar ve gelişmeler, (Eğitim Bilimine Giriş Ed. Ç. Özdemir), Ankara: Pegem Akademi.

Duman, T. H. Dilaver. (1996). İstanbul'da açlan İlk darülmuallimin kuruluş amacı müdürü ve hocalarının nitelikleri. tayin ve maaşları", Erdem. Cilt 9, (S. 26), ss. 651-662.

Ergün, M. (1982). Atatürk devri türk eğitimi. Ankara: A.Ü. Dil ve Tarih Coğrafya Fakültesi Yayınları, No:35.

Ergün, M. (1996). II. Meşrutiyet devrinde eğitim hareketleri (1908-1914), Ankara: Ocak Yayınları, ss. 314-316. 
Gelişli, Y. (2006). Öğretmen yetiştirmede Ankara yüksek öğretmen okulu uygulaması. İstanbul: Milli Eğitim Bakanlığı Yayınları: 3975.

Karagöz, S. (2005) “Kayseri Zincidere Köy Muallim Mektebi (1926 -1932)'nin Türkiye’de öğretmen yetiştirme tarihi içindeki yeri", Kayseri: Erciyes Üniversitesi, Sosyal Bilimler Enstitüsü ( Yayımlanmamış Yüksek Lisans Tezi).

Koçer, H.A. (1967). Türkiye'de öğretmen yetiştirme problemi (1848-1967), Ankara: Yargıçoğlu Matbaası, ss.16-20.

Koçer, H.A. (1975). “ Eğitim reformları açısından öğretmen yetiştirme problemi”, A.Ü Eğitim Fakültesi Dergisi, Cilt: 6, (S. 14), s.7.

Koçer, H.A. (1987). Türkiye'de modern eğitimin doğuşu. Ankara: Uzman Yayınları.

Öztürk, C. (1996). Atatürk deori öğretmen yetiştirme politikası, Ankara: Türk Tarih Kurumu Yayınları.

Unat, F. R. (1964). Türkiye eğitim sisteminin gelişmesine tarihi bir bakış. Ankara: Milli Eğitim Basımevi. 